\title{
Influence of Microfinance Banks on Rural Women's Entrepreneurial Success in Oyo State
}

\author{
Agnes Taiwo Hambolu, Ngozi Bibiana Nwabufor, and Acharu Faith Tony-Okeme
}

\section{ABSTRACT}

This focus of this paper is centered on the extent to which rural women entrepreneurs can be used as a vital tool for economic development in the State when availed micro credit. The paper discussed the rate at which the micro savings from microfinance banks influenced rural Women's entrepreneurial success in Oyo State. Two research questions were raised, two hypotheses were formulated and were tested at 0.05 level of significant. The study is premised on Gary Becker's human capital theory of entrepreneurship which stipulates that all human behavior is based on the economics of self-interest of individuals which operate freely within the competitive market, and Dunford Chris classical theory of microfinance. The instrument for data collection was personal interview and questionnaire tagged: Influence of Microfinance Banks on Rural Women's Entrepreneurial Success in Oyo State. This paper found that, rural women entrepreneurs significantly differ in their responses regarding extent to which micro credits influence their entrepreneurial success based on age grade. Also, the second finding revealed that single women entrepreneurs rated the influence of micro savings on their entrepreneurial success higher than the married women. However, micro savings for entrepreneurial purpose is good for both single and married rural women entrepreneurs for continuity of their businesses during financial crises. The study recommended that government should release fund to microfinance banks with specifications on sex and age so that women will be accessible to grants and loans with low interest in order to reduce poverty in our society especially among women.

Keywords: Entrepreneur, Microfinance banks, Rural Women, Success.
Submitted : March 21, 2021

Published : May 14, 2021

ISSN: $2507-1076$

DOI: $10.24018 /$ ejbmr.2021.6.3.826

Agnes Taiwo Hambolu*

(e-mail: agneshambolu1@gmail.com)

Ngozi Bibiana Nwabufor

Acharu Faith Tony-Okeme

*Corresponding Author

\section{INTRODUCTION}

Over the years, women entrepreneurs have been designated as the new engines for growth and the rising stars of the economies in developing countries to bring prosperity and welfare. A variety of stakeholders has pointed at them as an important 'untapped source' of economic growth and development [1]. Women are at the heart of development as they control most of the non-monetary economy (such as subsistence, agriculture, childbearing, and domestic labour) and play important roles in the monetary economy [2]. The woman as a person is an agent of reproduction of life itself. This places her in the position of the life-blood of the entire humanity. She is the first teacher, the sustainer and maintainer of the home, the peace maker, the symbol of beauty and major molder of the character of the child. She is a mother to the human race. As mother and wife, womanhood, to an extent, make considerable impact on the productivity of male workers. As workers in their own domains, women can conveniently be linked to the rejected stone in the Bible which had become the cornerstone of the house. By their sheer psychological, physiological, and intellectual make up, they do perform more than mere complimentary roles in the production process [3].

The growth of the proportion of women entrepreneurs in developing countries has drawn the attention of both the academic and the development sector. Donors, international public institutions, national and local governments, NGOs, private companies, charities, knowledge institutes and business associations have initiated programs or policies to promote and develop women's entrepreneurship. They initiate programs for capacity building of entrepreneurial skills, strengthening women's networks, provide finance and trainings, or design policies that enable more and stronger start-ups and business growth. They all claim that women entrepreneurship is essential for growth and development. Some even argue that women entrepreneurs' contribution tends to be higher than that resulting from entrepreneurial activity of men. In recent years, the general attention to women and entrepreneurship in developing countries has increased to a great extent and the focus on this 'untapped source' of growth seems to be indispensable nowadays for development practitioners and policy makers [1].

However, despite this growing number of initiatives and resources made available to promote and develop women's 
entrepreneurship in developing countries, women still own and manage fewer businesses than men, they earn less money with their businesses that grow slower, they are more likely to fail, and women tend to be necessarily entrepreneurs. Much of women's work remains invisible, unremunerated, and unrecognized. But women are now challenging the status quo. Mechanisms to right the so called "cultural wrongs" are being put in place. Women's voices are now being heard clamoring for an improvement in their socio-economic status and for the recognition of their immense contributions to national development [4]. The empowerment of women is one of the central issues in the process of development of countries all over the world. Poverty is one of the major reasons for women dis-empowerment hence different micro and macro level strategies are being adopted by government agencies and NGOs for poverty alleviation of women so as to empower them in Nigeria.

Microfinance bank has become an important Components of development, poverty reduction and economic regeneration strategy in Nigeria. Women entrepreneurs around the world are making a difference. They contribute numerous ideas, a great deal of energy and capital resources to their communities, generate jobs as well as create additional work for suppliers and other spin-off business linkages [5]. Women have been disadvantaged while competing with men in terms of remuneration despite their marital lifestyle engagement which require them to have babies, nurse children, and at the same time work for promotion in their places of work. Female entrepreneurs on the average make less than their male counterparts, while value added services per worker is lower in firms managed by women than those managed by men in Nigeria [6].

\section{StAtement OF THE PROBLEM}

Women entrepreneurships are vital to the economy of a nation with respect to economic development and poverty reduction. Entrepreneurs themselves have roles to play so as to complement government's effort in enterprise development. These include making good business decisions, having the right motive, making effort to acquire appropriate education or training, business experience or skills, innovation, market information, social networks, and so on. For a woman entrepreneur to succeed in her business, appropriate decision making is required of her especially in application of funds or credits acquired because misuse of acquired funds will result to business failure and continuous payment of interest. Other essential success attributes of entrepreneurs are entrepreneurial skills and ability to network [7]. Having the right motive, ambition, self-confident, high level of energy and being less emotional are other characteristics without which an entrepreneur may not succeed in her entrepreneurial activity. It has been observed that the survival rate of some micro-enterprises of the women in Nigeria especially in Oyo State is low. Most of the women entrepreneur access micro-credits from microfinance banks only to be used to settle other non-business issues. In spite of the little assistance from microfinance banks, poverty is still the characteristic Nigerian households [8].

Microfinance banks was introduced to educate and train rural women entrepreneurs on the technical knowhow needed for entrepreneurial success. The services needed to be successful in businesses such as micro credits, micro savings, financial advice, and so on. However, many studies have been carried out on rural women's entrepreneurial success. These include rural and urban entrepreneurs, comparison of service needs and delivery methods priority. Rural women entrepreneurial concept, the importance of rural women, are few among many [9], [10]. However, to the best knowledge of the researcher, none of the studies had worked on the influence of microfinance banks on rural women entrepreneurial success in Oyo State. This study is carried out to examine the influence of microfinance banks on rural women's entrepreneurial success in Oyo State, as well as enabling rural women entrepreneurs to know the extent at which they can benefit from the services rendered by microfinance banks without the use of collateral that serves as a barrier to accessing micro credits in carrying out their businesses.

\section{THEORETICAL BASES FOR THE STUDY}

\section{A. Human Capital Theory of Entrepreneurship by Gary Becker}

The original ideas of human capital theory can be traced back at least to Adam Smith in $18^{\text {th }}$ century. The modern theory was popularized by Gary Becker who was a Nobel Laureate and economist from the University of Chicago. It was originally developed to study the value of education [11], [12]. It also indicates that people have varying knowledge and skill that have economic value. Nonetheless, interest in human capital within the entrepreneurship literature is longstanding and has suddenly increased to a large extent over the last two decades. The theory was originally developed to explain variations in financial returns of employees and its application to entrepreneurship. This means that human capital theory is preferred to accomplishing goals about economic improvement.

According to Almendarez [13], human capital theory is considered to be the most influential economic theory of western education, setting the framework of government policies since the early 1960s modern human capital theory, all human behavior is based on the economics of self-interest of individuals operating within freely competitive market. The review of human capital theory begins in 1776 and ends in the 1960s, when the theoretical and empirical foundations were articulated and established. Human capital theory was also propounded for understanding both investment, incentives and the structure of wages and earnings. Human capital theory suggests that individuals and society derive economic benefits from investing in people. Human capital also include that stock, habits, knowledge, social and personality to perform labour so as to produce economic value. Human capital is unique and differs from any other capital. It is needed for campanies to achieve goals, develop and remain innovative.

Studies have found a positive association between human capital and economic development, which includes investments and productive growth. These associations have been used as evidence to justify government subsidies for training and knowledge acquisition. Human capital attributes 
such as, education and experience may also be critical for entrepreneurial success. From the human capital theory, it shows that women entrepreneurs, apart from having entrepreneurial skills it is necessary they use the skills they have aquired to influence other women entrepreneurs to be productive and successful in their entrepreneuial activities

\section{B. Classic Microfinance Theory by Dunford Chris}

Microfinance (MF) is referred to as micro credit, a form of banking service that is available to unemployed or lowincome persons or groups who otherwise have no access to financial services. This is one of the theories of microfinance that explained how low-level class can access micro credits, utilized the micro credits to start or expand a microenterprise.

Dunford [14] refers classic microfinance to a theory of change that involves three steps the poor person must take to make this theory true: Take a loan or save with a microfinance institution or similar entity, invest the money in a viable business and manage to yield major returns on the investment. Classic microfinance theory also states that it is low estimate of the possibility of using financial services, but it is a credible number. Chris Dunford theory of microfinance further explained that, taking a loan from or saving with a microfinance provides financial inclusion database that helps to be more productive on the evidence-based estimation of the percentage of a population that has access to financial services. This is one of the famous theories of microfinance that many successful entrepreneurs follow. This theory is related to the study because it examined the management of micro credits from microfinance banks not being diverted from entrepreneurial purposes.

\section{RESEARCH QUESTIONS}

The following research questions were raised and were answered to guide the study:

1. To what extent do micro credits influence rural women entrepreneurial success in Oyo State, Nigeria?

2. What is the extent that micro savings influence rural women entrepreneurial success in Oyo State, Nigeria?

\section{RESEARCH HYPOTHESES}

Based on the research questions, the following null hypotheses were formulated and tested at 0.05 level of significance.

$\mathrm{H}_{01}$ : There is no significant difference in the mean ratings of rural women entrepreneurs regarding the extent of the influence of micro credits on entrepreneurial success based on age grade.

$\mathrm{H}_{02}$ : There is no significant difference between the mean ratings of single and married rural women entrepreneurs regarding the extent of the influence of micro savings on their entrepreneurial success.

\section{Methodology}

The descriptive survey approach was used because the investigation centers on individuals and their opinions [15]. Similarly, Nwogu [16] stresses that descriptive survey research design used to collect data from every member of population or carefully selected sample to determine their views, beliefs, attitude, and behavior. The primary interest of this study is to ascertain the effects of microfinance banks on rural women's entrepreneurial success in Oyo State. The Population of the study covered the 54 registered rural women with the ministry of trade, industry, investment, and cooperative services Oyo State. Descriptive statistics of frequency count, mean and standard deviation were used to analyze the research questions while inferential statistical tool, analysis of variance and t-test were adopted to test the null hypotheses.

The research instrument that was appropriate for this study was personal interview and self-designed questionnaire tagged: Influence of microfinance banks on Rural Women's Entrepreneurial Success in Oyo State. (IMBRWES) The scale had two sections: Section A and B.

The section A consists demographic data of two items for the respondents. Section B consists of twenty (20) question items that aimed at eliciting responses of the participants as it relates to them. The study adopted the Modified Likert- rating scale format of: Very High Extent (VHE), Moderate Extent (ME), Low Extent (LE) and No Extent (NE) as instrument of the study.

For the purpose of admonishing the instrument in other to collect data for this study, the services of the two research assistants were employed with the researcher to cover the selected local governments in the senatorial districts in Oyo State. For the purpose of proper administration and collection of data, the research assistants were trained by the researcher in the proper administration of the instrument on the respondents. The demographic data was analyzed using frequency count and percentages. Mean and standard deviation values were used to analyze the research questions while, t-test, ANOVA and Sheffe Post Hoc test were used to analyze the null hypotheses.

\section{ANALYSIS OF DEMOGRAPHIC DATA}

The demographic data for the study were analyzed and presented in Table II to VI as follows:

TABLE i: PeRcentage Distribution of ReSPondents by AGE

\begin{tabular}{ccc}
\hline Age & Frequency & $\begin{array}{c}\text { Percentage } \\
(\%)\end{array}$ \\
\hline $21-30$ Years & 20 & 37.0 \\
$31-39$ Years & 18 & 33.3 \\
40 Years and above & 16 & 29.6 \\
Total & 54 & 100 \\
\hline
\end{tabular}

Source: Field survey, 2020.

Analysis of data in Table I shows the percentage distribution of respondents based on their age. The table reveals that there are twenty (20) respondents representing $37.0 \%$ who are between age 21 to 30 and 18 respondents representing $33.3 \%$ who are between Age 31 to 39 while 16 respondents representing $29.6 \%$ are between Age 40 years and above. This implied that majority of the respondents (women entrepreneurs) are between the age of 21 to 30 years. 
European Journal of Business and Management Research www.ejbmr.org

TABLE II: PERCENTAge Distribution OF RESPONDENTS By MARITAL STATUS

\begin{tabular}{ccc}
\hline Marital Status & Frequency & Percentage (\%) \\
\hline Single & 15 & 27.8 \\
Married & 39 & 72.2 \\
Total & 54 & 100 \\
\hline
\end{tabular}

Source: Field survey, 2020.

Analysis of data in Table II shows the percentage distribution of respondents based on marital status. The table reveals that there are fifteen (15) respondents representing $27.8 \%$ who are single and 39 respondents representing $72.2 \%$ who are married. This implied that majority of the respondents (women entrepreneurs) are married.

\section{ANALYSES OF DATA FOR ANSWERING THE RESEARCH QUESTIONS}

The research questions were analysed and presented in Table III and IV as follows:

Research Question 1: What is the extent of the influence of micro credits on rural women's entrepreneurial success in Oyo State, Nigeria?

TABLE III: MEAN AND STANDARD DEVIATION OF RESPONSES ON THE EXTENT OF THE INFLUENCE OF MICRO CREDITS ON RURAL WOMEN'S

\begin{tabular}{|c|c|c|c|c|}
\hline \multicolumn{5}{|c|}{ ENTREPRENEURIAL SUCCESS } \\
\hline $\begin{array}{l}\mathrm{S} / \\
\mathrm{N}\end{array}$ & Item Statements & $\bar{X}$ & SD & Remark \\
\hline 1. & $\begin{array}{l}\text { Microfinance banks help to } \\
\text { increase the capital base provided } \\
\text { for the rural women's enterprises. }\end{array}$ & 3.02 & 0.53 & $\begin{array}{l}\text { High } \\
\text { Extent }\end{array}$ \\
\hline 2. & $\begin{array}{l}\text { Lead to expansion of the rural } \\
\text { women's enterprises }\end{array}$ & 3.07 & 0.64 & $\begin{array}{l}\text { High } \\
\text { Extent }\end{array}$ \\
\hline 3. & $\begin{array}{l}\text { Have the ability to introduce new } \\
\text { products into the rural women's } \\
\text { businesses. }\end{array}$ & 3.35 & 0.95 & $\begin{array}{l}\text { High } \\
\text { Extent }\end{array}$ \\
\hline 4. & $\begin{array}{l}\text { Create the ability of exploring } \\
\text { new sources of supply of raw } \\
\text { materials for the rural women's } \\
\text { enterprises }\end{array}$ & 3.06 & 0.68 & $\begin{array}{l}\text { High } \\
\text { Extent }\end{array}$ \\
\hline 5. & $\begin{array}{l}\text { Enable the rural women to meet } \\
\text { up with the demands of } \\
\text { customers. }\end{array}$ & 3.09 & 0.59 & $\begin{array}{l}\text { High } \\
\text { Extent }\end{array}$ \\
\hline 6. & $\begin{array}{l}\text { Provide the opportunity for quick } \\
\text { access to fund credits in time of } \\
\text { emergency. }\end{array}$ & 3.09 & 0.59 & $\begin{array}{l}\text { High } \\
\text { Extent }\end{array}$ \\
\hline 7. & $\begin{array}{l}\text { Enable bulk purchase of goods or } \\
\text { products by the rural women }\end{array}$ & 3.09 & 0.59 & $\begin{array}{c}\text { High } \\
\text { Extent }\end{array}$ \\
\hline 8. & $\begin{array}{l}\text { Enable the building of } \\
\text { Warehouses for storage of the } \\
\text { rural women's goods }\end{array}$ & 3.04 & 0.55 & $\begin{array}{l}\text { High } \\
\text { Extent }\end{array}$ \\
\hline 9. & $\begin{array}{l}\text { Help rural women entrepreneur to } \\
\text { sustain their business }\end{array}$ & 2.83 & 0.47 & $\begin{array}{l}\text { High } \\
\text { Extent }\end{array}$ \\
\hline 10. & $\begin{array}{l}\text { Provide rural women with better } \\
\text { loan repayment interest which } \\
\text { does not put undue pressure on } \\
\text { them }\end{array}$ & 3.00 & 0.51 & $\begin{array}{l}\text { High } \\
\text { Extent }\end{array}$ \\
\hline & Weighted average & 3.06 & 0.61 & $\begin{array}{l}\text { High } \\
\text { Extent }\end{array}$ \\
\hline
\end{tabular}

Analysis of data in Table III shows mean responses on the extent of the influence of micro credits on rural women's entrepreneurial success. The table reveals that the respondents indicated that microfinance banks help to increase the capital base provided for the rural women's enterprises to high extent and lead to expansion of the rural women's enterprises (mean $=3.02$ and 3.07, respectively), the same way the respondents indicated that micro credits have the ability to introduce new products into the rural women's businesses at high extent and create the ability of exploring new sources of supply of raw materials for the rural women's enterprises to high extent (mean $=3.35$ and 3.06, respectively). In addition, the respondents indicated that micro credits enable the rural women to meet up with the demands of customers and provide the opportunity for quick access to fund credits to high extent in time of emergency as well as enable bulk purchase of goods or products by the rural women to high extent (mean $=3.09,3.09$ and 3.09, respectively). The respondents also indicated that micro credits enable the building of warehouses for storage of the rural women's goods to high extent and helps rural women entrepreneur to sustain their business to high extent as well as provide rural women with better loan repayment interest which does not put undue pressure on them (mean $=3.04$, 2.83 and 3.00, respectively).

All the ten (10) items constructed in the questionnaire have standard deviation ranging from 0.47 to 0.95 . This means that the responses of the respondents are not widespread as they are close to the mean. Table VII showed a ground calculated weighted average mean and standard deviation of 3.06 and 0.61 , which indicated that all the questions influence rural women's entrepreneurial success to high extent. This implied that micro credits positively influence rural women's entrepreneurial success to high extent in Oyo State, Nigeria (mean $=3.06, \mathrm{SD}=0.61$ ).

Research Question 2: To what extent do micro savings programmes influence the rural women's entrepreneurial success in Oyo State, Nigeria?

Analysis of data in Table IV shows mean responses on the extent of the influence of micro savings programmes on rural women's entrepreneurial success. The table reveals that the respondents indicated that micro savings programmes enable the assessment of the financial worth of businesses by the rural women to high extent, enable the rural women to prepare simple financial inventory for the business to high extent and increase micro credits obtained from the bank by the rural women to high extent (mean $=2.80,3.09$ and 3.09, respectively), the same way the respondents indicated that micro savings programmes prevent unnecessary spending by the rural women to high extent and determine the amount for purchasing of products or goods by the rural women to high extent as well as increase rural women's investments in various kinds of businesses to high extent (mean $=2.93,3.09$ and 3.09, respectively). In addition, the respondents indicated that the micro savings programmes help to organize trainings and seminars for rural women on how to invest the loans received from the bank to high extent and increase rural women's understanding and knowledge on the lending policy of the bank to high extent (mean $=3.09$ and 3.04, respectively). The respondents also indicated that micro savings programmes help rural women to accumulate more capital for expansion to high extent and broadens the knowledge of rural women entrepreneurs on other lending institutions (mean $=3.04$ and 3.02, respectively). 
TABLE IV: MEAN AND STANDARD DEVIATION OF RESPONSES ON THE EXTENT TO WHICH MICRO SAVINGS PROGRAMMES INFLUENCE THE RURAL WOMEN'S ENTREPRENEURIAL SUCCESS

\begin{tabular}{|c|c|c|c|c|}
\hline $\begin{array}{l}\mathrm{S} / \\
\mathrm{N}\end{array}$ & Item Statements & $\bar{X}$ & SD & Remark \\
\hline 1. & $\begin{array}{l}\text { Enable the assessment of the financial } \\
\text { worth of businesses by the rural women }\end{array}$ & 2.80 & 0.56 & $\begin{array}{l}\text { High } \\
\text { Extent }\end{array}$ \\
\hline 2. & $\begin{array}{l}\text { Enable the rural women to Prepare } \\
\text { simple financial inventory for the } \\
\text { business }\end{array}$ & 3.09 & 0.59 & $\begin{array}{l}\text { High } \\
\text { Extent }\end{array}$ \\
\hline 3. & $\begin{array}{l}\text { Increase micro credits obtained from } \\
\text { the bank by the rural women }\end{array}$ & 3.09 & 0.59 & $\begin{array}{l}\text { High } \\
\text { Extent }\end{array}$ \\
\hline 4. & $\begin{array}{l}\text { prevent unnecessary spending by the } \\
\text { rural women }\end{array}$ & 2.93 & 0.38 & $\begin{array}{l}\text { High } \\
\text { Extent }\end{array}$ \\
\hline 5. & $\begin{array}{l}\text { Determine the amount for purchasing } \\
\text { of products or goods by the rural } \\
\text { women }\end{array}$ & 3.09 & 0.59 & $\begin{array}{c}\text { High } \\
\text { Extent }\end{array}$ \\
\hline 6. & $\begin{array}{l}\text { Increase rural women's investments in } \\
\text { various kinds of businesses. }\end{array}$ & 3.09 & 0.59 & $\begin{array}{l}\text { High } \\
\text { Extent }\end{array}$ \\
\hline 7. & $\begin{array}{l}\text { Help to organize trainings and } \\
\text { seminars for rural women on how to } \\
\text { invest the loans received from the bank }\end{array}$ & 3.09 & 0.59 & $\begin{array}{c}\text { High } \\
\text { Extent }\end{array}$ \\
\hline 8. & $\begin{array}{l}\text { Increase rural women's understanding } \\
\text { and knowledge on the lending policy of } \\
\text { the bank }\end{array}$ & 3.04 & 0.73 & $\begin{array}{c}\text { High } \\
\text { Extent }\end{array}$ \\
\hline 9. & $\begin{array}{l}\text { Help rural women to accumulate more } \\
\text { capital for expansion }\end{array}$ & 3.04 & 0.73 & $\begin{array}{l}\text { High } \\
\text { Extent }\end{array}$ \\
\hline 10. & $\begin{array}{l}\text { Broadens the knowledge of rural } \\
\text { women entrepreneurs on other lending } \\
\text { institutions. }\end{array}$ & 3.02 & 0.60 & $\begin{array}{c}\text { High } \\
\text { Extent }\end{array}$ \\
\hline \multicolumn{2}{|c|}{ Weighted average } & 3.03 & 0.60 & $\begin{array}{l}\text { High } \\
\text { Extent }\end{array}$ \\
\hline
\end{tabular}

All the ten (10) items constructed in the questionnaire have standard deviation ranging from 0.38 to 0.73 . This means that the responses of the respondents are not widespread as they are close to the mean. Table 8 showed a ground calculated weighted average mean and standard deviation of 3.03 and 0.60 , which indicated that all the constructs influence rural women's entrepreneurial success to high extent. This implied that micro savings programmes positively influence rural women's entrepreneurial success to high extent in Oyo State, Nigeria $($ mean $=3.03, \mathrm{SD}=0.60)$.

\section{TEST OF HYPOTHESES}

The null hypotheses of the study were tested using Independent Analysis of Variance (ANOVA) and Post Hoc Test. The null hypotheses were tested at 0.05 level of significance. The summary of the test of hypotheses are presented in tables as follows:

$\mathrm{H}_{01}$ : There is no significant difference in the mean ratings of rural women entrepreneurs regarding the influence of micro credits on entrepreneurial success based on age grade.

TABLE V: SUMMARY OF ANOVA RESUlT SHOWING DIFFERENCE IN THE MEAN RATINGS OF RURAL WOMEN ENTREPRENEURS REGARDING THE INFLUENCE OF MICRO CREDITS ON ENTREPRENEURIAL SUCCESS BASED ON

\begin{tabular}{ccccccc}
\multicolumn{7}{c}{ AGE GRADE } \\
\hline Sources & $\begin{array}{c}\text { Sum of } \\
\text { Squares }\end{array}$ & Df & $\begin{array}{c}\text { Mean } \\
\text { Square }\end{array}$ & F & Sig. & $\begin{array}{c}\text { Decisi } \\
\text { on }\end{array}$ \\
\hline $\begin{array}{c}\text { Between } \\
\text { Groups }\end{array}$ & 10.416 & 2 & 5.208 & & & \\
$\begin{array}{l}\text { Within } \\
\text { Groups } \\
\text { Total }\end{array}$ & 6.717 & 51 & .132 & $\begin{array}{c}39.54 \\
2\end{array}$ & $\begin{array}{c}0.00 \\
0\end{array}$ & $\begin{array}{c}\text { Reject } \\
\text { ed }\end{array}$ \\
\hline Source: Field survey, 2020.133 & 53 & & & &
\end{tabular}

Source: Field survey, 2020.

The result of analysis of variance as presented in Table $\mathrm{V}$ reveals that the calculated value of $\mathrm{F}$ was $39.542\left(\mathrm{~F}_{51}=39.54\right)$ and the observed probability value is 0.000 which is less than the fixed probability value of $0.05(\mathrm{P}<0.05)$. This indicated that the null hypotheses which stated that there is no significant difference in the mean ratings of rural women entrepreneurs regarding the influence of micro credits on entrepreneurial success based on age grade was rejected. This implied that rural women entrepreneurs significantly differ in their responses regarding extent to which micro credits influence their entrepreneurial success based on age grade.

TABLE VI: SCHEFFE-POST HOC TEST

\begin{tabular}{cccc}
\hline (I) Age & (J) Age & $\begin{array}{c}\text { Mean Difference } \\
(\mathrm{I}-\mathrm{J})\end{array}$ & Sig. \\
\hline \multirow{2}{*}{$21-30$} & $31-39$ & .52500 & .000 \\
& 40 and above & $\begin{array}{c}1.088125 \\
-.52500\end{array}$ & .000 \\
$31-39$ & $21-30$ & .000 & .000 \\
& 40 and above & .55625 & -.000 \\
40 and above & $21-30$ & 1.08125 & .000 \\
\hline
\end{tabular}

Source: Field survey, 2020

Analysis of data in Table VI shows the Post Hoc test, which compare the ages of women entrepreneurs two at a time to see where the difference between the groups occurs. The table revealed that between the age 20-30 and 31-39, there was significant difference in the mean ratings of rural women entrepreneurs regarding the influence of micro credits on entrepreneurial success with a mean difference of 0.53 and $\mathrm{P}$-value of 0.000 which is less than the fixed probability value of 0.05 ( $\mathrm{P}<0.05)$. Same way, comparing age $31-39$ and $21-$ 30 , the table shows a mean difference of -0.53 and P-value of 0.000 which is less than the fixed probability value of 0.05 $(\mathrm{P}<0.05)$. This means that mean ratings of women entrepreneurs between ages 21-30 was higher than age 3139. The table also revealed that, comparing the difference in the mean ratings of women entrepreneurs between age 40 and above and 21-30, a significant difference exists as women with age 21-30 mean was higher with mean difference of 1.08 and P-value of 0.000 which is greater than the fixed probability value of $0.05(\mathrm{P}>0.05)$. With the result in Table 14 , it is clear that women entrepreneurs with age $21-30$ and 31-39 rated the influence of micro credits on entrepreneurial success higher that women with age 41 and above.

$\mathrm{H}_{02}$ : There is no significant difference between the mean ratings of single and married rural women entrepreneurs regarding the influence of micro savings on their entrepreneurial success.

TABLE VII: SUMMARY OF T-TEST OF THE DIFFERENCE BETWEEN THE MEAN RATINGS OF SINGLE AND MARRIED RURAL WOMEN

ENTREPRENEURS REGARDING THE INFLUENCE OF MICRO SAVINGS ON THEIR ENTREPRENEURIAL SUCCESS

\begin{tabular}{cccccccc}
\hline \multicolumn{1}{c}{ Troup } & $\mathrm{N}$ & Mean & SD & t-cal & Df & $\begin{array}{c}\mathrm{p}- \\
\text { value }\end{array}$ & Decision \\
\hline $\begin{array}{l}\text { Sin } \\
\text { Gle }\end{array}$ & 15 & 3.63 & 0.33 & & & & \\
Married & 39 & 2.79 & 0.45 & & 52 & 0.000 & Rejected \\
\hline $\begin{array}{l}\text { Source: Field survey, 2020. } \\
\text { P<0.05. }\end{array}$
\end{tabular}

The data in Table VII revealed that there are 15 single and 39 married women entrepreneurs. The single and married 
women entrepreneurs' responses showed that micro savings influence rural women entrepreneurial success to high extent $(\bar{X}=3.63 ; \mathrm{SD}=0.33)$ and $(\bar{X}=2.79 ; \mathrm{SD}=0.45)$. Their responses are close to the mean as the standard deviations are very low. The table revealed that there was significant difference between the mean ratings of single and married rural women entrepreneurs regarding the influence of micro savings on their entrepreneurial success $\left(\mathrm{t}_{52}=6.535, \mathrm{P}<0.05\right)$. Therefore, the null hypothesis that states that there is no significant difference between the mean ratings of single and married rural women entrepreneurs regarding the influence of micro savings on their entrepreneurial success was rejected. This implied that single and married rural women entrepreneurs differ in their responses regarding the influence of micro savings on their entrepreneurial success. Their responses showed that single women entrepreneurs rated the influence of micro savings on their entrepreneurial success higher than the married women did (mean difference $=0.84$ ).

\section{Results}

Micro credits positively influence rural women's entrepreneurial success to high extent (mean $=3.06, \mathrm{SD}=$ 0.61 , while the rural women entrepreneurs significantly differ in their responses regarding extent to which micro credits influence their entrepreneurial success based on age grade $\left(\mathrm{F}_{51}=39.54, \mathrm{P}<0.05\right)$.

Micro savings programmes positively influence rural women's entrepreneurial success to high extent (mean $=3.03$, $\mathrm{SD}=0.60$ ) and there was significant difference between the mean ratings of single and married rural women entrepreneurs regarding the influence of micro savings on their entrepreneurial success $\left(t_{52}=6.535, \mathrm{P}<0.05\right)$

The Post Hoc test of the finding compared the ages of women entrepreneurs two at a time to see where the difference between the groups occurs. The table revealed that between the age 20-30 and 31-39, there was significant difference in the mean ratings of rural women entrepreneurs regarding the influence of micro credits on entrepreneurial success. Same way, comparing age 31-39 and 21-30, the table shows a mean difference. This means that mean ratings of women entrepreneurs between age 21-30 was higher than age $31-39$. The result compared the difference in the mean ratings of women entrepreneurs between age 40 and above and 21-30, a significant difference exists as women with age 21-30 mean was high with the result, it is clear that women entrepreneurs with age 21-30 and 31-39 rated the influence of micro credits on entrepreneurial success higher that women with age 41 and above. Post hoc test was carried out to test the extent of the significant difference.

More so, it is concluded that, micro credits and micro savings were rated to have high positive influence on rural women's entrepreneurial success in Oyo State.

\section{DISCUSSION OF THE FINDINGS}

The study determined the influence of microfinance banks and cooperative societies on rural women Entrepreneurial success. Two services out of the services rendered by microfinance banks were examined in the study namely micro credits from microfinance banks, micro savings.

The first finding revealed that the rural women entrepreneurs significantly differ in their responses regarding extent to which micro credits influence their entrepreneurial success based on age grade. Maturity is expedient in entrepreneurship, few percentages of entrepreneurs that started at tender were successful [17]. The above revelation is in accordance with Akintokunbo, Adubasim \&Victor [18] who found that entrepreneurial innovativeness bears a positive and significant influence on performance of women entrepreneurs in Rivers State though the dimensions and measure variation the significance of relationships. The present finding agrees closely with the findings of Ayogu and Agu [17] which indicate that maturity brings self-fulfillment in entrepreneurship which significantly motivates women into entrepreneurship.

The second finding showed that single women entrepreneurs rated the influence of micro savings on their entrepreneurial success higher than the married women did whereby micro savings for entrepreneurial purpose is good for both single and married rural women entrepreneurs for continuity of their businesses during financial crises. This is highly in support of Abeh, Umar and Odekina [19] in Kogi State that, moderate positive coefficient of correlation of women desired to leave legacy to the family members which hinders many married to have huge savings for entrepreneurship. The present study agrees with the findings of Akerele and Aihonsu [20] that, women's family determine how successful they are going to be running the business enterprise most especially the aspect of savings and getting work for their business activities. The study also revealed that, many rural women entrepreneurs did not register their businesses with the ministry of trade, industry, investment and cooperative services, Oyo State.

\section{CONCLUSION}

Rural women entrepreneurs, irrespective of their age and location, esteemed micro credits and micro savings important to a high extent for entrepreneurial success. Microfinance banks services motivated and pulled rural women into entrepreneurship. Having researched into the concepts of microfinance and entrepreneurship, the researcher suggests and recommends that; government should release fund to the microfinance banks which would make the fund available to the micro credits with little interest so as to reduce poverty in the society especially among rural women. Government should set up a committee through microfinance banks that will help in supervising rural women entrepreneurs so as to ensure that micro credits from microfinance banks are not diverted from business purposes. Government should let the rural women entrepreneurs see the need of registering their businesses with the state ministry of commerce and industry. Prospecting rural women entrepreneurs should take bold step to identify and control the factors that reduce the saving habit of married rural women entrepreneurs for business purpose in their respective locations. Finally, government should also organize seminars, workshops, and trainings on small scale businesses for rural women entrepreneurs to educate them on the poverty alleviation programmes of the government. 


\section{APPENDIX}

Questionnaire on Influence of Microfinance Banks on Rural Women's Entrepreneurial Success (IMBCSRWES)

\section{Section A}

\section{Demographic Data:}

Please thick $[\sqrt{ }]$ the appropriate option and fill the space provided where applicable.

\section{Personal Data:}

1. Age range: 21-30 ( ) 31-39 ( ) 40 and above ( )

2. Marital Status: Married ( ) Single ( )

Very High Extent - (VHE)

Moderate Extent - (ME)

Low Extent - (LE)

No Extent - (NE)

\section{Section B1}

TABLE VIII: EXTENT TO WHICH MICRO CREDITS INFLUENCE RURAL

\begin{tabular}{cll}
\multicolumn{5}{c}{ WOMEN'S ENTREPRENEURIAL SUCCESS } \\
\hline S/N & \multicolumn{1}{c}{ Micro Credits } & VHE ME LE NE \\
\hline 1 & $\begin{array}{l}\text { Help to Increase the capital base } \\
\text { provided for the rural women's } \\
\text { enterprises. }\end{array}$ \\
2 & $\begin{array}{l}\text { Lead to expansion of the rural women's } \\
\text { enterprises }\end{array}$ \\
3 & $\begin{array}{l}\text { Have the ability to introduce new } \\
\text { products into the rural women's } \\
\text { businesses. }\end{array}$ \\
4 & $\begin{array}{l}\text { Create the ability of exploring new } \\
\text { sources of supply of raw materials for } \\
\text { the rural women's enterprises }\end{array}$ \\
5 & $\begin{array}{l}\text { Enable the rural women to meet up with } \\
\text { the demands of customers. }\end{array}$ \\
6 & $\begin{array}{l}\text { Provide the opportunity for quick access } \\
\text { to fund credits in time of emergency. } \\
7\end{array} \begin{array}{l}\text { Enable bulk purchase of goods or } \\
\text { products by the rural women } \\
8\end{array}$ \\
9 & $\begin{array}{l}\text { Enable the building of Warehouses for } \\
\text { storage of the rural women's goods } \\
\text { Help rural women entrepreneur to } \\
\text { sustain their business } \\
\text { Provide rural women with better loan } \\
\text { repayment interest which does not put } \\
\text { undue pressure on them }\end{array}$ \\
\hline
\end{tabular}

\section{Section B2}

TABLE IX: EXTENT TO WHICH MiCRo SAVINGS PROGRAMMES INFLUENCE RURAL WOMEN'S ENTREPRENEURIAL SUCCESS

\begin{tabular}{|c|c|c|c|c|c|}
\hline $\mathrm{S} / \mathrm{N}$ & Micro Savings Programmes & VHE & $\mathrm{ME}$ & $\mathrm{LE}$ & $\mathrm{NE}$ \\
\hline 1 & $\begin{array}{l}\text { Enable the assessment of the financial } \\
\text { worth of businesses by the rural women }\end{array}$ & & & & \\
\hline 2 & $\begin{array}{l}\text { Enable the rural women to Prepare } \\
\text { simple financial inventory for the } \\
\text { business }\end{array}$ & & & & \\
\hline 3 & $\begin{array}{l}\text { Increase micro credits obtained from the } \\
\text { bank by the rural women }\end{array}$ & & & & \\
\hline 4 & $\begin{array}{l}\text { Prevent unnecessary spending by the } \\
\text { rural women }\end{array}$ & & & & \\
\hline 5 & $\begin{array}{l}\text { Determine the amount for purchasing of } \\
\text { products or goods by the rural women }\end{array}$ & & & & \\
\hline 6 & $\begin{array}{l}\text { Increase rural women's investments in } \\
\text { various kinds of businesses. }\end{array}$ & & & & \\
\hline 7 & $\begin{array}{l}\text { Help to organize trainings and seminars } \\
\text { for rural women on how to invest the } \\
\text { loans received from the bank }\end{array}$ & & & & \\
\hline 8 & $\begin{array}{l}\text { Increase rural women's understanding } \\
\text { and knowledge on the lending policy of } \\
\text { the bank }\end{array}$ & & & & \\
\hline 9 & $\begin{array}{l}\text { Help rural women to accumulate more } \\
\text { capital for expansion }\end{array}$ & & & & \\
\hline 10 & $\begin{array}{l}\text { Broadens the knowledge of rural women } \\
\text { entrepreneurs on other lending } \\
\text { institutions. }\end{array}$ & & & & \\
\hline
\end{tabular}

\section{REFERENCES}

[1] M. Minniti and W, Naude "What Do We Know About The patterns and Determinants of Female Entrepreneurship Across Countries" European Journal of Development Research, vol. 22, pp. 277-293, Jun 2010 .

[2] A. David and G. Arancha "This is why women must play a greater role in the global economy" World Economic Forum Annual Meeting. May 2018.

[3] Ogunjemilua and J. Familugba, "The Contributions of Nigeria women Towards National Development" International Journal for Innovation Education and Research. Vol. 3 March 2015

[4] O. Amah "Gender and Accounting in Historical Perspective" https://www.ssrn.com April 2015.

[5] Obigbemi "Women Entrepreneurship in Nigeria: Policy Framework, Challenges and Remedies" scholsr.google.com, May 2015.

[6] M, Zetlin, "Women Entrepreneurs Pay Themselves 28 Percent lessThan Men Do. Here's Why They Say They Must. Women Entrepreneurship Report. https://www.inc.com, May 2018.

[7] M. Sussan T. Obamuyi, "The Impact of Microfinance Bank on Entrepreneurship Development in Nigeria. Journal of Business and Economic Development Science Publishing Group"vol. 3, pp. 51-61, Jun 2018 .

[8] V. Senibi, E. Oduntan, O. Uzoma, E. Senibi, and A. Oluwaseun, "Public Department and External Reserve: The Nigerian Experience (1981-2013)" Hindawi Economics Research International, https://www.hindawi.com/journal/ecri/2016/1957017 March 2016.

[9] A. Davis, "Rural and Urban Women Entrepreneurs: A Comparison of service needs and Delivery Method Priorities. International Journal of Business Science and Applied Management vol. 6 pp. 2 May 2011.

[10] M. Usman and M. Kwamba, "Determinants of Access to Entrepreneurial Credit: Examining Women Entrepreneurs in Sokoto State, Nigeria. Retrieved from European Journal of Business and Management, vol. 11 March 2019.

[11] G. Becker "Human Capital Theoretical and Empirical Analysis, with Special Reference to Education" New York: National Bureau of Economic Research: Distributed by Colombia University Press. Book Preview vol. 46 pp. 1, May 1964.

[12] T. Schultz "Investment in Human Capital: The Role of Education and of Research. American Journal of Agricultural Economics, vol. 53, pp. 692-693, March 1971.

[13] L. Almendarez "Human Capital Theory: implications for Educational Development in Belize and the Caribbean" Caribbean Quarterly vol. 59 pp. 21-33, Jun 2013.

[14] Dunford "Third step in the Microfinance Theory of Change: Manage the Business for Major ROI? The Evidence Project. May 2012.

[15] P. Arua Research Methodology. Lagos: Festac Printer Ltd, 2008.

[16] Nwogu "Education Research: Basic Issues and Methodology. Owerri: Wisdom Publishers, May 2016.

[17] U. Ayogu and O. Agu "Assessment of the Contribution of Women Entrepreneur towards Entrepreneurship" International Journal of Current Research and Academic Review, vol 3 pp. 190-207, March 2015.

[18] O. Akintokun, E. Adusasim and Victor "Entrepreneurial Innovativeness and Performance of Women Entrepreneurs in River State, Nigeria" Research Gate Article www.Researchgate. Net > Publication August 2018.

[19] Abeh, K.Umar and A. Odekina, "Family Factors and Women Entrepreneurial Motivation in Nigeria: A survey of Selected Women Entrepreneurs in Kogi State". International Journal of Science and Scientific and Research Publication vol.7 pp. 11 ISSN2250-31153 August, 2017.

[20] E. Akerele and J. Aihonsu, "Determination of Women's Participation in Entrepreneuship in Yerwa North Local Government Area, Ogun State, Nigeria" Nigerian Journal of Agricultural Economic (NJAE). vol.1, pp. 68-78 August 2011.

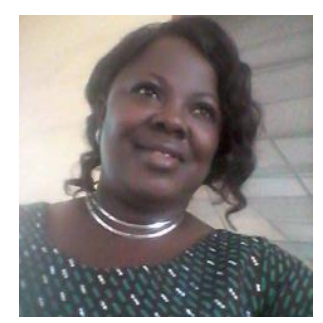

Hambolu Agnes Taiwo was born in Maiduguri metropolitan, Borno State, Nigeria. The Author obtained her Higher National Diploma in Marketing from Ramat Polytechnic, Maiduguri, Borno State, 2001 and Bachelor of Science in Business Administration from Joseph-Ayo Babalola University, Osun State, 2013. She went further to obtain her Post Graduate Diploma in Education from University of Ado-Ekiti, Ekiti State, 2010 and Masters in Business Education 2015 from Olabisi Onabanjo University, Ago Iwoye, Ogun State. 
She works as the Sales Supervisor with the Baptist Women's Missionary Union of Nigeria at the headquarters in Ibadan from 2010 till date. She was awarded the best staff of the month November, 2010 and May, 2013. She had authored five and co-authored three academic articles among which are Influence of Microfinance Banks and Cooperatives Societies on Rural Women's Entrepreneurial Success in Oyo State (Kentucky, USA: AJPO, 2021). Influence of Covid-19 on Rural Women's Entrepreneurial Success in Oyo State in European Journal of Business and Innovation Research (United Kingdom: ECRTD, 2020). And Availability and Utilization of Computers in Teaching and Learning Business Studies in Secondary Schools (Malete, kwara State: IP Integrity, 2020).

Mrs Hambolu is a member of Association of Business Educators of Nigeria (ABEN).

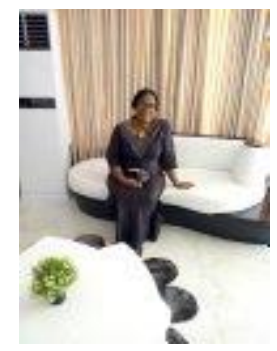

Dr. Ngozi Bibiana Nwabufo hails from Ogbunike in Oyi Local Govt. Area of Anambra State. She is happily married to a hardworking Anaesthetist, with five lovely and encouraging children.

She is a lecturer of Business Education (Marketing Option) at Kwara State University, Malete, Ilorin. She has attended and presented papers in many conferences (Local and International) and published many articles. She is eager to contribute to the growth of any organization, she finds herself in. Above all, she is hard working, very reliable and dependable in every task assigned to her. She is a Godfearing mother who has over the years combined excellently her career with maternal responsibilities on a balanced score.

She is a member of the Association of Business Educators of Nigeria, (ABEN).

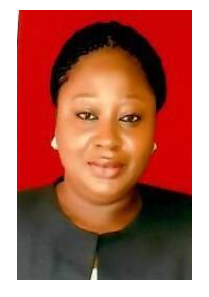

Mrs. Acharu Faith Tony-Okeme was born in Kawo, Kaduna, Nigeria. She holds a Bachelor's degree in Business Education from the Ahmadu Bello University Zaria, 2003 and a Master's degree in the same field from the same University in 2015.

She is a Principal Lecturer in the Department of Office Technology and Management, Kogi State Polytechnic, Lokoja. She was the Head of Office Technology and Management Department, Kogi State Polytechnic, Lokoja from January 2017 - July, 2020.

She has authored and co-authored eight academic books, amongst them are: Comprehensive Information Communication Technology Office Application (Lokoja, Kogi, Medupin Publisher, 2012), Research Techniques Simplified (Ibadan, Oyo State, Agunbay, 2016) and Elements of Management Information Systems (Ibadan, Oyo State, Agunbay, 2016). She also has to her credit, several scholarly articles published in reputable national and international journals.

Mrs Tony-Okeme is a member of many professional bodies among which are Association of Business Educator of Nigeria (ABEN), Teachers Registration Council of Nigeria (TR) and Member Business Educators in Vocational and Technical Education (BEAVE). 